\title{
Intestinal parasites of the bobcat (Lynx rufus) in areas surrounding Queretaro, Mexico
}

\author{
Brenda Camacho-Macías ${ }^{1}$, Norma Hernández-Camacho ${ }^{1 *}$, Germinal Jorge Cantó Alarcón², Claudia Irais Muñoz-García ${ }^{3}$, Rubén Pineda-López ${ }^{1}$, \\ Raúl Francisco Pineda-López ${ }^{1}$, Salvador Zamora-Ledesma ${ }^{1}$ and Marco Antonio Moreno-Pérez ${ }^{1}$. \\ ${ }^{1}$ Licenciatura en Biología, Facultad de Ciencias Naturales, Universidad Autónoma de Querétaro, Av. de las Ciencias s/n, CP. 76230, \\ Querétaro. Querétaro, México. E-mail: norma.hernandez@uaq.mx (NHC), camachomacb@gmail.com (BCM), rpineda62@ \\ hotmail.com (RPL), rpineda@uaq.mx (FRPL), szamora1405@gmail.com (SZL), biomamp1988@gmail.com (MAMP). \\ ${ }^{2}$ Licenciatura en Medicina Veterinaria y Zootecnia. Facultad de Ciencias Naturales, Universidad Autónoma de Querétaro, Av. de \\ las Ciencias s/n, CP. 76230, Querétaro. Querétaro, México. E-mail: gcanto07@uaq.mx (GJCA). \\ ${ }^{3}$ Departamento de Producción Agrícola y Animal. Universidad Autónoma Metropolitana. Unidad Xochimilco. Calzada del Hueso \\ 1100. Col. Villa Quietud, Delegación Coyoacán CP. 04960, Ciudad de México. México. E-mail: cimunoz@correo.xoc.uam.mx \\ (CIMG). \\ ${ }^{*}$ Corresponding author
}

The bobcat (Lynx rufus) is one of the carnivores most widely distributed in North America, coexisting with wild and domestic animals. Parasites reported for the bobcat in the United States and Canada are generalists typical of the order Carnivora. In Mexico, studies on parasites of carnivorous mammals are scarce due to their elusive nature, which makes difficult to obtain biological samples. Considering the available information about the bobcat in its northern distribution range, the community of intestinal parasites of this species was expected to comprise generalist parasites. The primary aim of this study was to determine the composition of the community of intestinal parasites in the bobcat (Lynx rufus) inhabiting areas surrounding the city of Queretaro, and investigate whether seasonal differences exist. The study was carried out in four sampling sites where Lynx rufus had been previously reported. Tracks were surveyed for scats in the rainy and dry seasons. Scats were analyzed using the Ritchie method supplemented with coprocultures and larval migrations. Parasites were identified based on specialized literature and prevalence was expressed in percentage. A $X^{2}$ test and a non-metric multidimensional scaling analysis were conducted to compare parasite species composition between sites and between seasons. A total of 83 scat samples were collected, 53 in the rainy season and 30 in the dry season. A total of seven parasite species were identified: Trichuris vulpis, Physaloptera praeputialis, Toxascaris leonina, Toxocara cati, Strongyloides stercolaris, Ancylostoma sp. and Uncinaria stenocephala. The prevalence of parasitized scats in both seasons was $75.9 \%$, with 73.6 $\%$ and $80 \%$ in the rainy and dry seasons, respectively. The $X^{2}$ test showed no significant differences between seasons $\left(X^{2}=0,553, d . f .=1, P=\right.$ 0.457). No differences were found in parasite species composition, either between seasons or between localities, according to the nonmetric multidimensional scaling analysis. The parasitic load of the bobcat in areas surrounding Querétaro is composed of generalist nematodes that are typical of carnivores. T. vulpis is recorded for the first time in L. rufus for Mexico. A high prevalence of S. stercolaris was observed, suggesting an interaction with human populations and domestic and wild animals, as reported in other studies on this same carnivore. This study is one of the first reports published on intestinal parasites of $L$. rufus in anthropic areas of Mexico, finding that the composition and structure of the parasite communities of this carnivore may indicate tolerance to disturbance derived from human activities.

El gato montés (Lynx rufus) es uno de los carnívoros con mayor distribución en Norteamérica, coexistiendo con animales domésticos y silvestres. Los parásitos que han sido reportados para el gato montés en Estados Unidos y Canadá son generalistas típicos del orden Carnivora. En México, los estudios sobre los parásitos de mamíferos carnívoros son escasos por su naturaleza elusiva que dificulta la obtención de muestras biológicas. Considerando la información disponible del gato montés para el norte de su distribución, se esperaba encontrar que la comunidad de parásitos intestinales de esta especie estuviera compuesta por parásitos generalistas. El objetivo general de este estudio fue conocer la composición de la comunidad de parásitos intestinales del gato montés (Lynx rufus) en la zona conurbada de Querétaro, así como determinar diferencias estacionales. El estudio se realizó en cuatro puntos de colecta donde se ha registrado previamente Lynx rufus. Se realizaron recorridos para búsqueda y colecta de excretas durante las temporadas de lluvias y secas. Las excretas se analizaron con la técnica de Ritchie, complementando con coprocultivos y migraciones larvarias. La identificación de parásitos se realizó con literatura especializada y su prevalencia fue expresada en porcentaje. Se hizo una prueba de $X^{2}$, así como un análisis de escalamiento multidimensional no métrico para comparar la composición de especies entre sitios y entre temporadas. Se colectaron 83 excretas en total, 53 en lluvias y 30 durante secas. Se identificaron en total siete especies: Trichuris vulpis, Physaloptera praeputialis, Toxascaris leonina, Toxocara cati, Strongyloides stercolaris, Ancylostoma sp. y Uncinaria stenocephala. La prevalencia de excretas parasitadas en ambas temporadas fue de $75.9 \%$, en lluvias $73.6 \%$ y en secas el $80 \%$. La prueba de $X^{2}$ no demostró diferencia significativa entre temporadas $\left(X^{2}=0.553, g . l .=1 P=0.457\right)$. No se encontró diferencia en la composición de especies entre temporadas ni entre localidades de acuerdo al análisis de escalamiento multidimensional no métrico. La carga parasitaria del gato montés en la zona conurbada de Querétaro está constituida por nemátodos generalistas de carnívoros. Se registra por vez primera a T. vulpis en L. rufus para México. Se encontró una alta prevalencia de S. stercolaris que podría significar una interacción con las poblaciones humanas, animales domésticos y silvestres según lo establecido en otros estudios con este mismo carnívoro. Este estudio es uno de los primeros publicados sobre parásitos intestinales de $L$. rufus en ambientes antropizados de México, en donde se encontró que la composición y estructura de las comunidades parasitarias de este carnívoro podría indicar la tolerancia a la perturbación por las actividades humanas.

Key words: Bobcat; Nematodes; Parasites; Querétaro; Trichuris vulpis.

C 2018 Asociación Mexicana de Mastozoología, www.mastozoologiamexicana.org 


\section{Introduction}

The bobcat (Lynx rufus) is one of the carnivores with the broadest distribution in North America, stretching from southern Canada to the Baja California peninsula and Oaxaca in Mexico (Hall 1981; Romero 1993; Larivière and Walton 1997; Romero 1993). This carnivore inhabits a range of environments, from pine, pine-oak and tropical deciduous forests, scrubs and grasslands, to areas with high human density, coexisting with domestic animals and wildlife (Gehrt et al. 2010). The bobcat has shown tolerance to fragmented environments (Riley et al. 2004), hence increasing the likelihood of contact with dogs and cats, with which it may potentially share the parasitic load (Harrison 1998; Medellín and Bárcenas 2009; Prough et al. 2009; Carver et al. 2012; Koleff et al. 2012; Valencia-Herverth and ValenciaHerverth 2012; Hiestand et al. 2014).

Parasites reported for the bobcat are generalists of wild and domestic mammals of the Order Carnivora, including Alaria marcianae, Taenia rileyi, Physaloptera Cylicospirura praeputialis, Felineus, Toxascaris leonina, T. mystax and Ancylostoma tubaeforme for West Texas (Stone and Pence 1978), while Paragonimus kellicotti, Spirometra mansonoides, $T$. macrocystis, T. leonina, T. mystax, A. tubaeforme, Oslerus rostratus, Molineus barbatus, Physaloptera rara and Troglostrongylus wilsoni were reported as typical components of the bobcat parasitic community for West Virginia and Georgia (Watson 1981). In a recent study, T. leonina, A. caninum, Ancylostoma spp., and Taenia spp. were reported as parasite species shared with other wild carnivores, such as coyotes (Canis latrans) and pumas (Puma concolor) (Hiestand et al. 2014), while L. rufus shares Toxocara cati with dogs and cats, mainly when the former lives in urbanized areas where contact with domestic animals has been reported (Riley et al. 2004; Keesing et al. 2006; Carver et al. 2012; Mino-Botello et al. 2016).

In recent years, a number of ecological studies have been conducted on the bobcat in Mexico, making it possible to broaden its distribution range with new records (Valencia-Herverth and Valencia-Herverth 2012), identifying differences in feeding patterns (Medellín and Bárcenas 2009), or evaluating the effect of landscape attributes on its presence (Botello et al. 2006; Monroy and Briones-Salas 2012; García- Prieto et al. 2014; López-González et al. 2015; Espinosa-Flores and Lopez-González 2016), to mention a few examples. In Mexico, only three parasite species have been formally registered for the bobcat, according to the information available in the National Collection of Helminths at the Institute of Biology, UNAM. These records correspond to two nematodes, Toxascaris leonina and Physaloptera praeputialis, and one cestode, Echinococcus oligarthra (Salinas-Lopez et al. 1996; García-Prieto et al. 2012). Specifically, for the study area, there is one study on the presence of a cyst in the intestinal mucosa of a bobcat, and the presence of the nematode $P$. praeputialis is reported for the first time for the state of Querétaro (Lopez-González et al. 2012). Last, the presence of endoparasites has been reported in several mesocarnivores inhabiting the Ajusco, including L. rufus (Gallardo 2014).

The scarce biological information available on parasites of wildlife hinders the development of prevention and control strategies and measures in the event of potential zoonoses of importance for humans. Toxocara cati is considered as a species with zoonotic potential. Previous studies have reported a higher prevalence of this species in areas where wild and domestic animals are found in sympatry, in turn increasing the likelihood of contact with humans (Bevins et al. 2012).

The objective of this study was to determine the composition of the parasite community in the faeces of the bobcat (Lynx rufus) inhabiting areas surrounding the city of Queretaro, and testing for significant differences in parasite composition and prevalence between seasons. Based on the available information on the composition and structure of the parasite communities of the bobcat living in disturbed environments in the United States. We expected to find a community of intestinal parasites dominated by generalist species, typically associated with the presence of domestic animals and habitat loss, in areas surrounding the city of Queretaro.

\section{Materials and Methods}

Study Area. The study was carried out in four collection sites in areas surrounding the city of Queretaro: El Cimatario National Park (PANEC), Joya-La Barreta Recreational Area, ExHacienda La Machorra and the area adjacent to Los Angeles dam in Mompani, all sites where the presence of Lynx rufus has been reported (Figure 1).

El Cimatario National Park is surrounded by peripheral suburbs of the city of Queretaro. It is located at $20.474^{\circ}$ to $20.556^{\circ} \mathrm{N}$, and $-100.326^{\circ}$ to $-100.386^{\circ} \mathrm{W}$, with a reported area of $2,447 \mathrm{ha}$. It is a protected natural area dominated

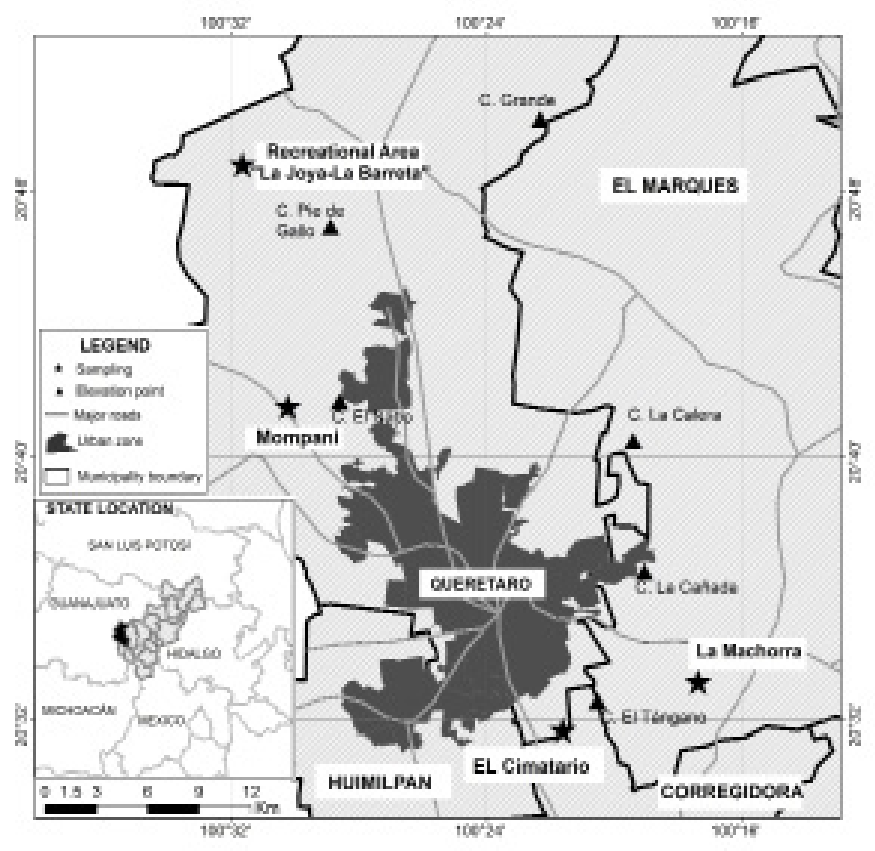

Figure 1. Scat collection sites in areas surrounding the city of Queretaro, Mexico. 
by crasicaule (thick-stemmed) scrub and tropical deciduous forest (Baltasar et al. 2004; López-González et al. 2015). The PANEC is listed as a protected natural area where grazing, reforestation, firewood collection, hiking and cycling activities take place.

The Joya-La Barreta Recreational Area, located in the Santa Rosa Jauregui delegation, is part of the Santa Catarina micro-watershed in the boundary between the States of Queretaro and Guanajuato $\left(20.809^{\circ} \mathrm{N},-100.528^{\circ} \mathrm{W}\right)$. It comprises six vegetation types, mainly oak forest, natural grassland, petrophytic vegetation (in ravines and gullies) and crasicaule scrub. Its primary functions are ecological conservation and special protection, but subsistence activities such as grazing and soil and firewood extraction are conducted in the area, as well as recreational activities like camping and hiking. The area of influence of the park includes locations such as La Barreta, La Carbonera and La Joya, where primaryproduction activities such as maize cultivation, nomadic livestock raising and firewood collection for domestic use are performed (Hernández-Sandoval et al. 2005).

Mompani is a rural town where the "Los Angeles" dam is located, in coordinates $20.711^{\circ} \mathrm{N},-100.506^{\circ} \mathrm{W}$. It is surrounded by secondary vegetation, crasicaule scrubs, agricultural areas and hills covered with tropical deciduous forest where livestock raising and firewood collection for domestic use are conducted (Pineda-Lopez et al. 2010).

Ex-Hacienda "La Machorra" is located in the municipality El Marqués between communities El Rosario and Los Cués, in coordinates $20.554^{\circ} \mathrm{N},-100.286^{\circ} \mathrm{W}$. The land is covered by crasicaule scrub vegetation where livestock raising is not practiced but materials such as gravel and stone are extracted. To note, groups of feral dogs were observed in and around collection sites during sampling periods, due to the proximity of human settlements.

Scat Collection and Examination. Tracks were surveyed weekly in search of scats and latrines during the rainy season (late May, July, September and October 2015) and the dry season (early March and May 2016). Surveys were performed at 1-week intervals to ensure the independence of individual scats collected, as suggested in HernándezCamacho et al. (2011).

Scat samples were identified in the field based on shape (cylindrical and in clusters), size (approx. 1.5 to $2.5 \mathrm{~cm}$ wide by 10.0 to $15.0 \mathrm{~cm}$ long), color (usually light gray or blackish when fresh), composition (mostly hair and bone remains), and association with lynx tracks adjacent to scats (Aranda 2012). Only fresh scats that did not break apart upon handling were sampled, to avoid weathering and ensure the potential presence of parasite dispersal stages. Scat samples were split into two halves, one was placed inside a polyethylene bag with zipper and fixed with $10 \%$ formalin following the methodology of Hernández-Camacho et al. (2011). The other half was placed in a paper bag to be tested for coproculture and as source of replicate samples.
Scat samples were labeled with the respective collection data (sample number, date, collection site and georeference), and were stored at $4{ }^{\circ} \mathrm{C}$ until analysis.

Stool ova, parasite and coproculture tests. Stool samples were analyzed with the Ritchie float or formalin-ether test to extract protozoan eggs, cysts and oocysts (Medina et al. 1994; Hernández-Camacho et al. 2011; Aranda et al. 2013). Parasite eggs were identified based on morphometry under a LEICA ICC50 HD light microscope using the software LAS EZ Leica Application Suite version 3.1.1. Scat cultures and larval migration tests were conducted aiming to obtain $\mathrm{L}_{3}$ larvae (Medina et al. 1994). The taxonomic identification of eggs was confirmed under the microscope, by comparison with the specialized literature (Taylor et al. 2007; Bowman et al. 2011).

Statistical analysis. The total prevalence of parasites by locality was expressed in percentage and was quantified as the number of scat samples infected with any parasite divided by the total number of scats per collection locality and multiplied by 100 . A Chi-square $\left(X^{2}\right)$ test was performed to assess potential differences between the collection seasons. The species composition of parasite communities was compared between sites and between seasons through a non-metric multidimensional scaling (NMDS) analysis, which is usually the method of choice for the graphical representation of relationships at the community level (Clarke 1993). This analysis was performed using the Jaccard similarity index and the software PAST 2.17c (Hammer et al. 2001).

\section{Results}

A total of 83 scat samples were collected for both seasons, 53 and 30 during the rainy and dry seasons, respectively. Parasite eggs were identified to the lowest taxonomic level possible, identifying a total of seven nematode species for the bobcat: Trichuris vulpis, P. praeputialis, T. leonina, T. cati, S. stercolaris, Uncinaria stenocephala and Ancylostoma sp.

A total prevalence of $75.9 \%(n=63)$ was observed in the two collection seasons. For the rainy season, $73.6 \%$ of scat samples $(n=39)$ tested positive for at least one of the six nematode species. S. stercolaris was the species with the highest prevalence in the four sites (33.3\% in La Machorra and $100 \%$ in El Cimatario); the species with the lowest prevalence were T. leonina (13.3\%) and T. vulpis (20 $\%)$, which were found in only one site (La Machorra). For the dry season, $80 \%$ of scats tested positive $(n=24)$, with $T$. cati and S. stercolaris as the most prevalent parasites, both with a $100 \%$ prevalence in El Cimatario; T. vulpis showed a very low prevalence, observed only in Mompani (12.5\%). The $X^{2}$ test showed no significant differences in nematode species between seasons $\left(X^{2}=0.553\right.$, d. $\left.f .=1, P=0.457\right)$. The non-metric multidimensional scaling (NMDS) analysis revealed no differences in species composition between seasons (Figure 2). Hence, this parameter was similar across collection sites. T. leonina was found only during the rainy 
season, and $U$. stenocephala, during the dry season; both parasite species were found only in La Machorra.

\section{Discussion}

The parasitic load of the bobcat in areas surrounding the city of Querétaro consists of nematodes; this differs from what is recorded for scat samples collected in the United States, where a greater parasite diversity has been observed,

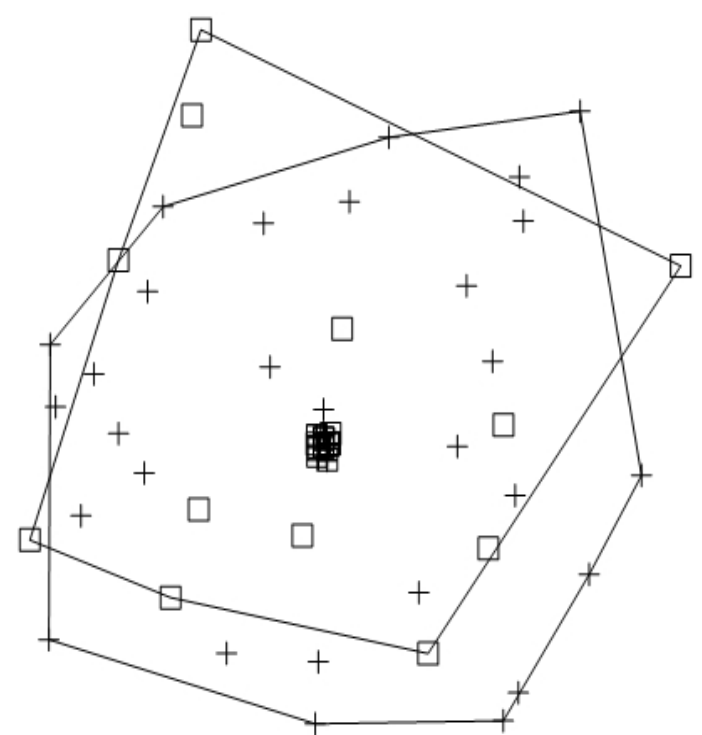

Figure 2. Plot of the non-metric multidimensional scaling of the species composition between the two seasons. White boxes indicate parasites recorded during the rainy season; crosses, parasites recorded in the dry season. Polygons represent seasons, the overlap shows that the composition of parasite communities is similar across sites, regardless of season.

including trematodes, cestodes, protozoans, and acanthocephalans (Stone and Pence 1978; Watson 1981; Tiekotter 1985; Larivière and Walton 1997; Hiestand et al. 2014); however, all the nematode species recorded are generalists of carnivores, which is consistent with our expectations. The technique used for the analysis of stools is suitable for the detection of the dispersal stages of many parasites (Hernández-Camacho et al. 2011). The presence of nematodes as the only parasite group may be the result of the different dispersal and transmission strategies used by these organisms, favoring their survival in anthropic environments, as is the case of the host-infection strategy or larva migrans, which penetrates through the skin of foot pads, as well as transplacental and transmammary transmissions (Anderson 2000). This great variety of options contrasts with those in other parasite groups, such as trematodes, cestodes and acanthocephalans, all of which require trophic transmission via intermediate hosts to complete their life cycle in the definitive host (Bush et al. 2001).

Some of the nematode species found in this study have also been recorded in feral dogs from the outskirts of Querétaro, such as S. stercoralis and Ancylostoma sp. (Fernández et al. 2002; Cantó et al. 2011), and in the gray fox (Urocyon cinereoargenteus), also with S. stercoralis (Hernández-Camacho et al. 2011), to mention a few examples. T. vulpis is recorded for the first time in L. rufus for Mexico at La Machorra and Mompani; this parasite was previously observed in scat of gray fox at El Cimatario (Hernández-Camacho et al. 2011).

Strongyloides stercoralis showed a $100 \%$ prevalence in the dry season at El Cimatario National Park. This finding may indicate the contact of bobcats with humans and domestic animals, as suggested in the study of Mino-Botello et al. (2016) in the Tehuacán-Cuicatlán Biosphere Reserve. In the specific case of El Cimatario, the presence of packs of feral dogs has been documented (Hernández-Camacho et al. 2016), which interact with wild carnivores (HernándezCamacho pers. com. 2017). This is similar to the situation mentioned by Mino-Botello et al. (2016).

The identification of Ancylostoma sp. to species level was not possible, despite the observation of distinctive characters in eggs and larvae obtained from scat cultures. However, A. tubaeforme and A. caninum have been recorded in bobcats in the United States (Stone and Pence 1978; Watson 1981; Hiestand et al. 2014). In the area adjacent to Santiago de Queretaro, A. caninum has been observed in stools of feral dogs and gray foxes; therefore, the Ancylostoma eggs and larvae found in this study likely correspond to this species.

Toxocara cati is the most prevalent parasite in wild and domestic cats (Bowman 2011). In this study, its prevalence was low relative to the other nematodes found. This parasite can be transmitted directly when eggs are ingested or through paratenic hosts such as mice of the genus Peromyscus (Aranda et al. 2002; Bowman et al. 2002; García-Prieto et al. 2012).

No significant differences were found in the composition of the parasite community between seasons, except for T. leonina and U. stenocephala in La Machorra. The presence of $T$. leonina in the rainy season may be due to its life cycle being favored by moisture and low temperatures, as well as by the presence of eggs and $L_{3}$ larvae in tissues of rodents of the genus Peromyscus (Anderson 2000; Bowman et al. 2011). The species recorded during the dry season may be fostered by the presence of artificial water bodies in the study sites, which are favorable for the survival of the dispersal stages. Other studies have reported that the eggs of Toxocara sp. and Trichuris sp. are resistant to various environmental factors, and hence remain viable in soil for months (Mizgajska 2001; Rendón-Franco et al. 2013), until there are suitable conditions for completing their life cycle.

Each of the four localities in this study show some degree of anthropization, from El Cimatario National Park, an area under conservation strategies, to areas with intense human activity in La Machorra, associated with the extraction of construction materials, and Mompani, related to the Santiago de Queretaro landfill. All the localities studied recorded parasite species that are generalists and resilient to environmental disruption, which may point to the historical presence of human activities in these sites (HernándezCamacho et al. 2016). 
The parasite species found are generalists typical of carnivores, with life strategies that allow them to survive and persist in environments with anthropic activities. This could indicate that the areas surveyed in this study have undergone a steady long-term loss of biodiversity, where the intermediary hosts of several parasite species are no longer in the area (Lafferty 1992; Lafferty 2012, HernándezCamacho et al. 2016). On the other hand, domestic and wild carnivores interact as predators and competitors. This leads to a significant impact on wild populations, with a negative effect on the trophic structure of the remaining ecosystems in the areas around cities. This may have negative health effects on local inhabitants, by being increasingly closer to zoonotic parasites (Riley et al. 2004; Gehrt et al. 2010; Sepúlveda et al. 2014).

\section{Acknowledgments}

Thanks to M. T. Ponce Gaxiola and F. Smith Beltran for their support in field work; to S. L. Sosa Gallegos, a technician of the Microbiology Laboratory at the Faculty of Veterinary Medicine and Animal Sciences, Universidad Autónoma de Queretaro for the advice; as well as to E. Romero Callejas for guidance in the identification of the parasite eggs in the Parasite Diagnosis Laboratory at Universidad Nacional Autónoma de México during the stay of the first author in September 2016. This study was financed by Red Temática de Biología, Conservación y Manejo de la Fauna Nativa en Ambientes Antropizados (Thematic Network for Biology, Conservation and Management of the Native Fauna in Anthropized Environments, REFAMA). Special thanks to M. C. Pantoja Hernández for the elaboration of the map. This study was partially funded by the project PRODEP UAQPTC-313 DSA/103.5/16/10199. María Elena Sánchez-Salazar translated the manuscript into English.

\section{Literature cited}

Anderson, R. C. 2000. Nematode parasites of vertebrates: Their development and transmission. Second edition. $C A B$ International. Ontario, Canadá.

Aranda, M., O. Rosas, J. D. J Rios, and N. García. 2002. Análisis comparativo de la alimentación del gato montés (Lynx rufus) en dos diferentes ambientes de México. Acta Zoológica Mexicana 87:99-109.

ArandA-SÁNCHEZ, J. M. 2012. Manual para el rastreo de mamíferos silvestres en México. Comisión Nacional para el Conocimiento y uso de la Biodiversidad. Ciudad de México, México.

Aranda, R., E. Serrano-Martínez, M. Tantaleán, M. Quispe, and G. CASAS. 2013. Identificación y frecuencia de parásitos gastrointestinales en félidos silvestres en cautiverio en el Perú. Revista de Investigaciones Veterinarias del Perú 24:360-368.

Baltasar, J. O. R., M. Martínez, and L. S. Hernández. 2004. Guía de plantas comunes del Parque Nacional "El Cimatario" y sus Alrededores. Universidad Autónoma de Querétaro. Querétaro.
Bevins, S. N., Carver, S., Boydston, E. E., Lyren, L. M., Alldredge, M., Logan, K. A., And Salman, M. 2012. Three pathogens in sympatric populations of pumas, bobcats, and domestic cats: implications for infectious disease transmission. PLoS One. 7:31403.

Botello, F., P. Illoldi-Rangel, M. Linaje, and V. Sánchez-Cordero. 2006. Primer registro del tigrillo (Leopardus wiedii, Schinz 1821) y del gato montés (Lynx rufus, Kerr 1792) en la Reserva de la Biosfera de Tehuacán-Cuicatlán, Oaxaca, México. Acta Zoológica Mexicana 22:135-139.

Bowman, D., E. Fogarty, and B. S. Charles. 2002. Parasitology: Diagnosis and treatment of common parasitisms in dogs and cats. Teton NewMedia CRC Press. Jackson, U. S. A.

BoWmAn, D. D. 2011. Georgis' parasitology for veterinarians. Elsevier Health Sciences. St. Louis, U. S. A.

Bush, A. O., J. C. Fernández, G. W. Esch, and J. R. Seed. 2001. Parasitism. The diversity and ecology of animal parasites. Cambridge University Press. New York, U. S. A.

Carver, S., A. V. Scorza, S. N. Bevins, S. P. Riley, K. R. Crooks, S. VANDEWOUDE, AND M. R. LAPPIN. 2012. Zoonotic parasites of bobcats around human landscapes. Journal of Clinical Microbiology 50:3080-3083.

Cantó, G. J., P. M. García, M. J. Guerrero, and J. Mosqueda. 2011. The prevalence and abundance of helminth parasites in stray dogs from the city of Querétaro in Central México. Journal of Helminthology 85:263-269.

Ceballos, G., and G. Oliva. 2005. Los mamíferos silvestres de México. Fondo de cultura económica. Comisión Nacional para el Conocimiento y uso de la Biodiversidad. Ciudad de México, México.

ClaRKE, K. R. 1993. Non-parametric multivariate analyses of changes in community structure. Australian Journal of Ecology 18:117-143.

Espinosa-Flores, M. E., AND C. A. López-GonzÁlez. 2016. Landscape attributes determine bobcat (Lynx rufus escuinapae) presence in Central Mexico. Mammalia 81:101-105.

FERNÁNDEZ, C. F., AND G. J. CANTÓ-AlarCón. 2002. Intestinal helminth frequency in stray dogs sacrificed in the city of Querétaro, in the state of Queretaro, in Mexico. Veterinaria México 33:247-253.

Gallardo Santis, M. A. 2014. Endoparásitos en heces de linces, coyotes y perros que habitan un paisaje fragmentado del Ajusco, Distrito Federal, México. Tesis que para obtener el título de Médico Veterinario Zootecnista. Universidad Nacional Autónoma de México.

García-Prieto, L., J. Falcón-Ordaz, and C. Guzmán-Cornejo. 2012. Helminth parasites of wild Mexican mammals: list of species, host and geographical distribution. Zootaxa 3290:1-92.

García, J. A. M., G. D. Martínez, P. Plata, O. C. R. Rosas, L. A. T. Arámbula, AND L. C. BENDER. 2014. Use of prey by sympatric bobcat (Lynx rufus) and coyote (Canis latrans) in the Izta-Popo National Park, Mexico. The Southwestern Naturalist 59:167-172.

GehRT, S. D., RILEY, S. P., AND CYPHeR, B. L. 2010. Urban carnivores: ecology, conflict, and conservation. JHU Press. Maryland, U. S. A.

Gotelu, N. J., AND A. M. ELLISon. 2004. A primer of ecological statistics. Sinauer Associates Inc. Publishers. Sunderland, U. S. A. 
HaLL, R. E. 1981. The Mammals of North America. John Wiley and Sons. New York, U. S. A.

Hammer, Ø., D. A. T. Harper, and P. D. Ryan. 2001. PAST: Paleontological statistics software package for education and data analysis. Palaeontologia Electronica 4:1-9 pp. http:// palaeo-electronica.org/2001 1/past/issue1 01.htm

HARRISON, R. L. 1998. Bobcats in Residential Areas: Distribution and Homeowner Attitudes. The Southwestern Naturalist 43:469-475.

Hernández-Sandoval, L., R. Pineda-Lopez, and E. Ongay-Delhumeau. 2005. Plan Rector de operación del parque "Joya La Barreta". Licenciatura en Biología. Facultad de Ciencias Naturales. Universidad Autónoma de Querétaro. Disponible en norma. hernandez@uaq.mx

Hernández-Camacho, N., R. Pineda-López, C. A. López-González, and R. W. JONES. 2011. Nematodes parasites of the gray fox (Urocyon cinereoargenteus Schreber, 1775) in the seasonally dry tropical of Central Mexico. Parasitology Research 108:1425-1429.

Hernández-Camacho, N., R. F. Pineda-López, M. J. Guerrero-Carrillo, G. J. Cantó Alarcón, R. W. Jones, M. A. Moreno-Pérez, J. J. MosquedaGualito, S. Zamora Ledesma, and B. Camacho-Macías. 2016. Gray fox (Urocyon cinereoargenteus) parasite diversity in central Mexico. International Journal for Parasitology: Parasites and Wildlife 5: 207-210.

Hiestand, S. J., C. K. Nielsen, And F. A. Jiménez. 2014. Epizootic and zoonotic helminths of the bobcat (Lynx rufus) in Illinois and a comparison of its helminths component communities across the American Midwest. Parasite 21:4.

Keesing, F., R. D. Holt, and R. S. Ostfeld. 2006. Effects of species diversity on disease risk. Ecology Letters 9:485-498.

Koleff, P., T. Urquiza-Haas, and B. Contreras. 2012. Prioridades de conservación de los bosques tropicales en México: Reflexiones sobre su estado de conservación y manejo. Revista Ecosistemas 21:6-20.

LAFFERTY, K. D. 1992. Environmental parasitology: what can parasites tell us about human impacts on the environment? Parasitology today 13:251-255.

LAFFERTY, K. D. 2012. Biodiversity loss decreases parasite diversity: theory and patterns. Philosophical Transactions of the Royal Society 367:2814-2827

LARIMĖE, S., AND R.WALton. 1997. Lynx rufus. Mammalian Species 563:1-8. López-González, C. A., M. J. Guerrero-Carrillo, N. HernándezCamacho, and P. J. Aranda-Vargas. 2012. Presencia de nódulos en la mucosa estomacal e intestinal asociados a la presencia de Physaloptera praeputialis (Spirurida: Physalopteridae) en gato montés (Lynx rufus) del Parque Nacional El Cimatario, Querétaro, México: estudio de un caso". XXI Congreso de Patología Veterinaria, realizado del 30 de mayo al $1^{\circ}$ de junio de (2012) en León, Guanajuato.

López-González, C., D. Ávila-Aguilar, and M. F. Cruz-Torres. 2015. Bobcat abundance (Lynx rufus escuinapae J. A. Allen.1903) in the National Park El Cimatario, Querétaro, México. Acta Zoológica Mexicana 31:138-140.

Medellín-Legorreta, R. A., and H. V. Bárcenas. 2009. Estimación de la densidad poblacional y dieta del lince (Lynx rufus) en Aguascalientes y el Distrito Federal, México. Universidad Nacional Autónoma de México. Instituto de Ecología.
Informe final SNIB-CONABIO proyecto ESO03. Ciudad de México, México.

Medina, R. U., R. Loalza-Reyes, L. Velueta, and J. Díaz-Romero. 1994. Manual de técnicas de diagnóstico en parasitología veterinaria. Universidad Juárez Autónoma de Tabasco. Villahermosa, México.

Mino-Botello, D. D., E. Romero-Callejas, O. E. Ramírez-Bravo, and A. Aguilar-Ubeda. 2016. Determinación de parásitos gastrointestinales en carnívoros en el centro de México. Acta Zoológica Mexicana (n. s.) 32:210-212.

MIZGAJSKA, H. 2001. Eggs of Toxocara spp. in the environment and their public health implications. Journal of Helminthology 75:147-151.

Monroy, G., and M. Briones-Salas. 2012. Primeros datos sobre área de actividad de gato montés (Lynx Rufus) en Oaxaca, México. Acta Zoológica Mexicana 28:471-474.

PéreZ-PONCE dE LEÓN, G. 2001. The diversity of Digeneans (Platyhelminthes: Cercomeria: Trematoda) in Vertebrates of Mexico. Comparative Parasitology 68:1-8.

Pineda-López, R., N. Febvre, and M. Martínez. 2010. Importancia de proteger pequeñas áreas periurbanas por su riqueza avifaunística: el caso de Mompaní, Querétaro, México. Huitzil 11:69-77.

Prough, L. R., C. J. Stoner, C. W. Epps, W. T. Bean, W. J. Ripple, A. S. LALIBERTE, AND J. S. BRASHARES. 2009. The rise of the mesopredator. Bioscience 59:779-791.

Rendón-Franco, E., E. Romero-Callejas, C. Villanueva-García, D. Osorio-SARABIA, AND C. I. Muñoz-GarCía. 2013. Cross transmission of gastrointestinal nematodes between captive neotropical felids and feral cats. Journal of Zoo and Wildlife Medicine 44:936-940.

Riley, S. P., J. Foley, And B. Chomel. 2004. Exposure to feline and canine pathogens in bobcats and gray foxes in urban and rural zones of a National Park in California. Journal of Wildlife Diseases 40:11-22.

Romero, F. 1993. Análisis de la alimentación del lince (Lynx rufus escuinapae) en el volcán Pelado, Ajusco, México. Pp: $217-$ 230 in Avances en el estudio de los mamíferos de México (Medellín, R., and G. Ceballos, eds.). Publicaciones Especiales No. 1. Asociación Mexicana de Mastozoología, A. C. Ciudad de México, México.

Salinas-López N. F., C. Jiménez-Guzman, and A. Cruz-Reyes. 1996. Presence of Echinococcus oligarthus (Diesing 1863) Lühe, 1910 in Lynx rufus texensis Allen, 1895 from San Fernando, Tamaulipas State, in north east Mexico. International Journal for Parasitology 26:793-796.

Sepúlveda, M. A., R. S. Singer, E. Silva-Rodríguez, P. Stowhas, and K. Pelican. 2014. Domestic dogs in rural communities around protected areas: conservation problem or conflict solution? PLoS one 9 e86152.

Stone, J., and D. Pence. 1978. Ecology of helminth parasitism in the Bobcat from West Texas. The Journal of Parasitology 64:295-302.

TaYlor, M. A., R. L. CoOp. AND Wall, R. L. 2007. Veterinary parasitology. Blackwell Publishing. Oxford, UK.

TIEKOTTER, K. L. 1985. Helminth species diversity and biology in the bobcat, Lynx rufus (Schreber), from Nebraska. The Journal of Parasitology 71:227-234. 
Valencia-Herverth, R., and J. Valencia-Herverth. 2012. Presencia del gato montés (Lynx rufus) en selvas tropicales del estado de Hidalgo, México. Therya 3:81-85.

Watson, T. G., V. F. Nettles, And W. R. Davidson. 1981. Endoparasites and selected infectious agents in bobcats (Felis rufus) from West Virginia and Georgia. Journal of Wildlife Diseases 17:547-554.

Associated editor: Rafael Avila

Submitted: May 31, 2017; Reviewed: July 15, 2017;

Accepted: November 11, 2017; Published on line: January 15, 2018. 
HELMINTHS OF BOBCAT IN MEXICO.

14 THERYA Vol. 9(1): 7-13 